\title{
UV-B Induced Effects and Repair Mechanism in Aquatic Cyanobacteria
}

\author{
Ruchi Rai and Rai LC* \\ Department of Botany, Banaras Hindu University, India
}

Submission: February 11, 2017; Published: March 27, 2017

*Corresponding author: Rai LC, Distinguished Professor, Department of Botany, Molecular Biology Section, Laboratory of Algal Biology, Centre of Advanced Study, Banaras Hindu University, Varanasi-221005, India, Tel: +91- 542-6701110; Fax: +91- 542-2368174;

Email: lcrbhu15@gmail.com

\section{Mini Review}

Stratospheric depletion of ozone layer has resulted in an increase in the solar UV-B radiation (280 to $320 \mathrm{~nm}$ ) reaching the Earth's surface. UV-B radiation is potentially harmful to all forms of life but is more detrimental to photosynthetic organisms, including cyanobacteria. Cyanobacteria are the largest and most widely distributed group of photosynthetic prokaryotes on the Earth, and their contribution to global $\mathrm{CO}_{2}$ and $\mathrm{N}_{2}$ fixation is remarkable. These organisms are proficient in fixing atmospheric nitrogen using enzyme nitrogenase hence potentially recognized as a biofertilizer in rice paddies [1] and other crops. They are important constituent of aquatic ecosystem which is one of the most productive and diverse ecosystem thus any alteration in the size and composition of phytoplankton communities will directly affect its productivity. Hence, it is quite relevant to study the effects of ultraviolet (UVB) radiation on them. The aquatic ecosystem has shown a large sensitivity towards increased solar ultraviolet radiation resulting in decreased biomass productivity, reduced food production for humans [2], reduced sink capacity for atmospheric carbon dioxide $[3,5,6]$ as well as changes in species composition and ecosystem integrity. In cyanobacteria, UV-B radiation has been found to affect a number of physiological and biochemical processes such as growth, survival, cell differentiation, motility, pigmentation, photosynthesis, nitrogen metabolism, and protein profile $[7,8,9]$. It also affects membrane permeability, pigment stability, nutrient uptake mechanisms and signal transduction through phytochrome or specific UVB photoreceptors [10] Portwich [11]; Kumar et al. [12]; Cadoret et al. [13]. However, enzymes such as nitrate reductase, glutamine synthetase and glutamate synthase are less sensitive to elevated level of UV-B intensity [14] and the response of cyanobacteria towards UV-B radiation differs in various species. DNA and photosynthesis are recognized as the most predominant targets of UV-B [15]. It has been shown that UV-B affects the photosynthetic electron transport and pigment-protein complexes in cyanobacteria by photobleaching of photosynthetic pigments, reduction in phycobili protein content and disassembly of phycobilisome complex [16]. Additionally, several studies have demonstrated that UV-B radiation affects spectral properties of pigments specifically chlorophyll a and phycobiliproteins of cyanobacteria [8] and also influences the chlorophyll and carotenoids contents in cyanobacteria $[8,17,18]$. Observed a down regulation of transcripts including mRNAs specifying proteins involved in light harvesting and photosynthesis after UV-B exposure. The photosynthetic parameters such as $\mathrm{CO}_{2}$ uptake, $\mathrm{O}_{2}$ evolution and ribuolose-1, 5 bisphosphate carboxylase/oxygenase (RUBISCO) activities are also down regulated [9].

The D1 and D2 proteins that are major constituent of PSII reaction center are degraded by exposure of UV-B. Exposure of UV-B radiation also results in significant alterations of total protein profile of cyanobacteria [16]. Total proteome analysis of Synechocystis sp. PCC 6803 by 2-dimensional (2-D) gel electrophoresis showed different level of proteins expression in the cytoplasm under short and long-term UV-B stress [18]. Cyanobacteria exposed to UVR have evolved a number of mitigation strategies to reduce its direct and indirect damaging effects. The first line of protective strategies include migration from high level to low level of UV intensity in water column, formation of mats/crust, changes in morphology or synthesis of extracellular polysaccharides i.e.gypsum crystals. To escape from high solar radiation, motile cyanobacteria in mats often migrate up and down-wards depending on the spectral waveband [19]. In planktonic cyanobacteria, sinking and floating regulated by gas vacuoles are also protective strategies against UVR [20]. Another mode of defense is the generation of antioxidants in response to reactive oxygen species generated during UV-B stress. The enzymatic antioxidants are superoxide dismutase (SOD), catalase, glutathione peroxidase (GSH-Px) and the enzymes involved in the ascorbate-glutathione cycle to detoxify the ROS such as ascorbate peroxidase (APX), monodehydroascorbate 
reductase (MDHAR), dehydroascorbate reductase (DHAR) and glutathione reductase (GR) [21]. Exposure of DNA to UV-B causes several types of DNA lesions, which are mainly repaired by photoreactivation (light-dependent) and excision repair (light-independent) mechanism. Photoreactivation occurs with the help of the photolyase enzyme that specifically binds to cyclobutane-pyrimidine dimers (CPDs) or 6-4 photo-lyase (6-4PPs) and reverses the damage after absorption of light energy at $400 \mathrm{~nm}$ [22]. The major photo reactivating factor phrA in the Cyanobacterium Synechocystis sp. PCC6803 codes for a cyclobutane-pyrimidine dimer-specific DNA photolyase. In the excision repair process, various enzymes (e.g. glycosylases or polymerases) are involved. First, the damaged DNA is nicked and then the short single strand segments are important role in photoprotection as they are located in the extracellular glycan layer covalently linked to oligosaccharides [23,24]. In most cyanobacteria, however, MAAs is located in the cytoplasm, where only $10-26 \%$ of harmful radiation is absorbed by this compound [25]. Besides acting as sunscreens, MAAs may provide additional protection as antioxidants [26]. Another UV-absorbing component known for UV-screening properties in cyanobacteria is scytonemin which is formed by condensation of tryptophan and phenyl-propanoid derived subunits [27]. Cyanobacteria may also undergo apoptosis or programmed cell death (PCD) when a cell is damaged beyond repair. An autocatalytic PCD induced by high irradiance was found to operate in the nitrogen-fixing Cyanobacterium Trichodesmium sp. [28]. The caspase activity involved in PCD was observed in Microcystis aeruginosa [29] as well in Trichodesmium sp. [28] implicating the role of PCD under oxidative stress [30-35].

\section{References}

1. Banerjee M, Hader DP (1996) Effects of UV Radiation on the Rice Field Cyanobacterium Auloszru fertzlzssima. Env Exp Bot 36(3): 281-289.

2. Hader DP, Worrest RC (1997) Consequences of the Effects of Increased Solar Ultraviolet Radiation on Aquatic Ecosystems, In: Htider DP (Ed.), The Effects of Ozone Depletton on Aquatic Ecosystems, Chapter 3, Environmental Intelligence Unit, Academic Press and RG Landes Company, Austin pp. 11-30.

3. Ducklo, HW, Carlson CA, Bates NR, Knap AH, Michaels AF, et al. (1995) Dissolved Orgamc Carbon as a Component of the Biological Pump in the North Atlantic Ocean. Phzl Trans R Sot Lond B 348(1324): 161167.

4. Htider M and Hlider DP (1997) Optical Properties and Phytoplankton Composition in a Fresh water Ecosystem (Main-Donau-Canal), In: Htider DP (Ed.), The Effects of Ozone Depletton on Aquatic Ecosystems, Chapter 9, Environmental Intelligence Unit, Academic Press and RG Landes Company, Austin, pp. 155-174.

5. Takahashi T, Takahashi TT, Sutherland SC, Williams RG (1995) An Assessment of the Role of the North Atlantic as a $\mathrm{CO}_{2}$ Sink. Phd Trans R Sot Lond B 348(1324): 143-152.

6. Takahashi T, Feely RA, Weiss RF, Wannmkhof RH, Chapman DW, et al (1997) Global An-sea Flux of $\mathrm{CO}_{2}$ : An Estimate Based on Measurements of Sea-air p CO ${ }_{2}$ Difference. Proc Natl Acad Sci USA, 94(16): 8292-8299.

7. Häder DP, Kumar HD, Smith RC, Worrest RC (2007) Effects of solar UV radiation on aquatic ecosystems and interactions with climate change. Photo chem Photobiol Sci 6(3): 267-285.
8. Gao K, Yu, H, MT Brown (2007) Solar PAR and UV radiation affect the physiology and morphology of the Cyanobacterium Anabaena sp. PCC 7120. J Photo chem Photobiol B Biol 89(2-3): 117-124.

9. Sinha RP, HäderDP (2008) UV-protectants in cyanobacteria. Plant Sci 174(3): 278-289.

10. Vincent WF, Roy S (1993) Solar ultraviolet-B radiation and aquatic primary production: damage, protection and recovery. Environ Rev 1: $1-12$.

11. Portwich A, Garcia-Pichel F (2000) A novel prokaryotic UVB photoreceptor in Cyanobacterium Chlorogloeopsis PCC 6912. Photo chem Photobiol 71(14): 493-498.

12. Kumar A, Tyagi MB, Jha PN, Srinivas G, Singh A (2003) Inactivation of cyanobacterial nitrogenase after exposure to ultraviolet-B radiation. Curr Microbiol 46(5): 380-384.

13. Cadoret JC, Rousseau B, Perewoska I, Sicora C, Cheregi O, et al. (2005) Cyclic nucleotides, the photosynthetic apparatus and response to UV-B stress in the Cyanobacterium Synechocystis sp. PCC 6803. J Biol Chem 280(40): 33935-33944.

14. Kumar A, Sinha, RP, Häder DP (1996) Effect of UV-B on enzymes of nitrogen metabolism in the Cyanobacterium Nostoc calcicola. J Plant Physiol 148: 86-91.

15. Singh SP, Klisch M, Sinha RP, Häder DP (2010) Genome mining of mycosporine-like amino acid (MAA) synthesizing and non-synthesizing cyanobacteria: a bioinformatics study. Genomics 95(2): 120-128.

16. Sinha RP, Kumar A, Tyagi MB, Häder DP (2005) Ultraviolet-B-induced destruction of phycobiliproteins in cyanobacteria. Physiol Mol Biol Plants 11(2): 313-319.

17. He YY, Häder DP (2002) Involvement of reactive oxygen species in the UV-B damage to the Cyanobacterium Anabaena sp. J Photochem Photobiol B Biol 66(1): 73-80.

18. Gao Y, Xiong W, Li XB, Gao CF, Zhang YL, et al. (2009) Identification of the proteomic changes in Synechocystis sp. PCC 6803 following prolonged UV-B irradiation. J Exp Bot 60(4): 1141-1154.

19. Bebout BM, Garcia-Pichel F (1995) UV-B induced vertical migrations of cyanobacteria in a microbial mat. Appl Environ Microbiol 61(12): 4215-4222.

20. Reynolds CS, Oliver RL, Walsby AE (1987) Cyanobacterial dominance: the role of buoyancy regulation in dynamic lake environments. $\mathrm{N} \mathrm{Z} \mathrm{J}$ Mar Freshwater Res 21(3): pp. 379-390.

21. He YY, Hader DP (2002) Reactive oxygen species and UV-B: effect on cyanobacteria. Photo chem Photobiol Sci 1(10): 729-736.

22. Sinha RP, DP Häder (2002) UV-induced DNA damage and repair: a review. Photochem Photobiol Sci 1(4): 225-236.

23. Böhm GA, Pfleiderer W, Böger P, Scherer S (1995) Structure of a novel oligosaccharide-mycosporine-amino acid ultraviolet $A / B$ sunscreen pigment from the terrestrial Cyanobacterium Nostoc commune. J Biol Chem 270(15): 8536-8539.

24. Ehling-Schulz M, Bilger W, Scherer S (1997) UV-B-induced synthesis of photoprotective pigments and extracellular polysaccharides in the terrestrial Cyanobacterium Nostoc commune. J Bacteriol 179(6): 19401945.

25. Garcia-Pichel F, Wingard CE, Castenholz RW (1993) Evidence Regarding the UV Sunscreen Role of a Mycrosporine-Like Compound in the Cyanobacterium Gloeocapsai sp. Appl Environ Microbiol 59(1): 170-176.

26. Dunlap WC, Yamamoto Y (1995) Small-molecule antioxidants in marine organisms- antioxidant activity of mycosporine-glycine. Comp Biochem Phys B Biochem Mol Biol 112(1): 105-114. 
27. Proteau PJ, Gerwick WH, Garcia-Pichel F, Castenholz R (1993) The structure of scytonemin, an ultraviolet sunscreen pigment from the sheaths of cyanobacteria. Experientia 49(9): 825-829.

28. Berman-Frank I, Bidle KD, Haramaty L, Falkowski PG (2004) The demise of the marine Cyanobacterium Trichodesmium spp., via an autocatalyzed cell death pathway. Limnol Oceanogr 49(4): 997-1005.

29. Frangeul L, Quillardet P, Castets AM, Humbert JF, Matthijs HCP, et al. (2008) Highly plastic genome of Microcystis aeruginosa PCC 7806, a ubiquitous toxic freshwater cyanobacterium. BMC Genomics 9: 274

30. Ross C, Santiago-Va' zquez L, Paul V (2006) Toxin release in response to oxidative stress and programmed cell death in the Cyanobacterium Microcystis aeruginosa. Aquat Toxicol 78(1): 66-73.

31. He YY, Häder DP (2002) UV-B-induced formation of reactive oxygen species and oxidative damage of the Cyanobacterium Anabaena sp: protective effects of ascorbic acid and N-acetyl-L-cysteine. J Photochem Photobiol B Biol 66(2): 115-124.

32. Levine E, Thiel T (1987) UV-inducible DNA repair in the Cyanobacteria Anabaena sp. J Bacteriol 169: 3988-3993.

33. Sass L, Spetea C, Mate Z, Nagy F, Vass I (1997) Repair of UV-B induced damage of Photosystem II via de novo synthesis of the D1 and D2 reaction centre subunits in Synechocystis sp. PCC 6803. Photosynth Res 54(1): 55-62

34. Mohamed A, Jansson C (1989) Influence of light on accumulation of photosynthesis-specific transcripts in the Cyanobacterium Synechocystis 6803. Plant Mol Biol 13(6): 693-700.

35. Sinha RP, Dautz M, Häder DP (2001) A simple and efficient method for the quantitative analysis of thymine dimers in cyanobacteria, phytoplankton and macroalgae. Acta Protozool 40: 187-195.

\section{Your next submission with Juniper Publishers will reach you the below assets}

- Quality Editorial service

- Swift Peer Review

- Reprints availability

- E-prints Service

- Manuscript Podcast for convenient understanding

- Global attainment for your research

- Manuscript accessibility in different formats

( Pdf, E-pub, Full Text, Audio)

- Unceasing customer service

Track the below URL for one-step submission https://juniperpublishers.com/online-submission.php 